\title{
Erratum
}

\section{Humanism, philology and the medievalist}

\section{Seth Lerer}

Literature Department, University of California, San Diego, CA.

postmedieval: a journal of medieval cultural studies (2015) 6, 111. doi:10.1057/pmed.2015.7

Correction to: postmedieval: a journal of medieval cultural studies 5, 502-516 (Winter 2014). doi: 10.1057/pmed.2014.34

A typographical error was introduced to this review essay.

The phrase

Charles Eliot Norton - the polymathic president of Harvard who died in 1908 -

Should read

Charles Eliot Norton - the polymathic professor at Harvard who died in 1908 -

We apologize to the author and reader for any confusion caused. 